\title{
Wilhelm Brauneder Europäische Privatrechtsgeschichte
}

\author{
(Böhlau Verlag GmbH \& Co KG, Wien Köln Weimar, 2014, pp 278 \\ UTB-Band-Nr 3487 / ISBN 978-3-8385-3487-9, Euro 24,99)
}

Although this is, to the best of my knowledge, the latest addition to studies on the history of European private law, it does not presume to supplant any of the previous works, such as the monumental historical gems of Franz Wieacker, Privatrechtsgeschichte der Neuzeit unter besonderer Berücksichtigung der deutschen Entwicklung (1967) and Paul Koschaker, Europa und das Römische Recht (1966). It does, however, give a useful overview (the author refers to it as a Grundriss or outline) of the history of European law in historical context.

After an introduction distinguishing private and public law, and defining European legal history in the context of domestic law (heimisches Recht), German law, Roman and common law (gemeines Recht), canon law and natural law, the author presents his subject in fifteen chapters, commencing in the Middle Ages and continuing to modern times. He rounds it off with a section on sources, a bibliography, a list of abbreviations, a list of illustrations and a succinct index of topics and persons.

Chapter 1 deals with development during the Middle Ages. It commences with domestic law as developed in various communities, with the focus on customary law (Gewohnheitsrecht) in such forms as provincial, municipal and rural law (Landrecht, Stadtrecht and Hofrecht). This introduces a comparative slant in its reference to the various European legal spheres, including the French, Hispanic (Iberian), Italian, Scandinavian, German (Deutsche Recht) and the common law of England. It is, of course, the various aspects of German law on which the focus is primarily placed, more particularly topics such as property, family, persons and succession, all of which have their origin in Roman and Byzantine law and were further developed

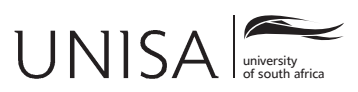


during the medieval rebirth in the time of the Glossators, Commentators, Humanists, Canonists and the school of Natural Law.

Chapter 2 deals with the English common law in historical perspective. Aspects of law such as the various forms of trust are given particular emphasis because of their uniqueness. The German Treuhand has been likened to it. Reference is also made to the fact that Scots law underwent a separate development and, perhaps more importantly, that the common law was transferred to the various parts of the British Empire, such as South Africa, where it linked up with Roman-Dutch law to become a substantive portion of the "mixed" legal system of which South African lawyers are justifiably proud. This was followed by further extension of this mix between common law and "civil law" to other parts of Africa and also to places like Srilanka (Ceylon), Louisiana in the United States of America and Quebec in Canada.

In chapter 3 the author turns to the phase of development to which he refers as die frühe Neuzeit in the sense of the "early modern period" commencing with the humanitarian or "elegant" jurisprudence (humanistische or elegante Jurisprudenz) of the sixteenth century. Central to this development was the Roman Corpus Iuris Civilis (the Code of the Emperor Justinian) which gave rise to what became known as the "Italian custom" (mos italicus) and the "French custom" (mos gallicus) of Europe. This overview is followed by a discussion of what the author terms "the so-called reception" of Roman law into Europe, more specifically Germany, where it is called "Römisch-Deutsche Recht" or Ius Romano-Germanicum. This reflected a nationalisation of the common law and a legal dualism between what Johann Gottlieb Heineccius (1681-1741) referred to as "the elements of the civil (Roman) law" (Elementa Iuris Civilis) and "the elements of the German law" (Elementa Iuris Germanici). The chapter is concluded with a brief discussion of marriage law in canonical private law, with specific reference to Catholic and Evangelical differentiation.

The Roman-Germanic law (Ius Romano-Germanicum), as the basis of "a new legal culture" (eine neue Rechtskultur) and a peculiarly German common law (deutches Gemeinrecht), is dealt with in somewhat more detail in chapter 4. A basic principle or rule applicable in this regard is that this common law was, in general, subsidiary to local or domestic law, but this could differ from one region to another. This subsidiary application came to be known as "the modern use of the Pandects" (usus modernus pandectarum)," being the name of a well-known work by Samuel Stryk (1640-1710). The author points out that this German common law developed over approximately two centuries until it was supplanted by the natural law codifications such as the Allgemeines Landrecht (ALR) of Prussia (1794) and the Allgemeines Bürgerliches Gesetzbuch (ABGB) of Austria (1811). In countries without codifications it continued into the eighteenth century as Germanic or Pandectist legal science (Germanistik and Pandektistik) in the works of a number of 
accomplished jurists and in various legislative enactments. It was likewise prevalent in legal practice in a variety of forms.

Chapter 5 deals briefly with the origin and development of Scandinavian (Nordic) law in Denmark, Norway, Sweden, Iceland and Finland inasmuch as it accords to a certain extent with that of Germany, particularly with regard to a wide range of legislation. Canon law likewise played a role in this regard, more particularly in the law of marriage and succession. Roman law, however, was not as influential as in Germany except, perhaps, after 1650 when universities in Denmark and Sweden began placing greater emphasis on the importance of Romano-Germanic and RomanDutch law in the seventeenth and eighteenth centuries.

Natural law as such is dealt with in chapter 6 . The author speaks in this regard of the doctrine of the law of reason (Vernunftrecht), in the sense of law or legal principles emanating from human nature, as opposed to positive law (positives Recht). In historical context natural law could be traced back to the Greek philosophical schools of Plato and Aristotle, from whom it progressed via Cicero and the Stoa to St Augustine, Thomas Aquinas and the late-Scholasticism of the sixteenth and seventeenth centuries. From there it moved to individual exponents of natural law such as the Dutch jurist Hugo Grotius (1583-1645), with his famous De iure belli ac pacis, and German jurists like Samuel Pufendorf (1632-1694), Gottfried Wilhelm Leibniz (1646-1716) and Christian Thomasius (1655-1728). They played an important role in developing aspects of private law during the period prior to natural law codifications.

The prominence of natural law codifications in European legal development prompted the author to deal specifically with such codifications in chapter 7. The idea was to reduce the mass of sources into a code containing the relevant principles in an easily accessible unit. Predecessors of the famous natural law codifications were the 1750 Prussian code of King Friedrichs II (Corpus Iuris Fridericiani) and the 1756 Bavarian civil law code of Maximilian III (Codex Maximilianeus Bavarius Civilis). The Prussian Allgemeines Landrecht für die Preusisschen Staaten (ALR) of 1794, which contained both private and public law in some 20,000 paragraphs, was the first natural law codification of substance. These early codes were, as might be expected, largely supplanted by the German civil code (Bürgerliches Gesetzbuch or BGB) when it came into operation on 1 January 1900.

Prior to that, however, the French civil code (Code Civil) of 1804, a product of the French Revolution and Napoleon Bonaparte's initiatives (hence also known as the Code Napoléon), became widely influential throughout Europe. In its 2,300 paragraphs it dealt with many aspects of private law and effectively put an end to the distinction between French customary law (droit coutumière) and written law (droit écrit). It was in fact translated into German for use in German states as Napoleons Gesetzbuch until the BGB replaced it in 1900. It was similarly applicable in the 
Netherlands until 1838 when the Burgerlijk Wetboek was promulgated and in Italy until 1865 when the Codice Civile came into operation.

The natural law codification process in Austria was pre-empted by a code of Emperor Leopold I of 1671 (Codex Leopoldinus) and the civil code of the Habsburg Monarchy of 1704 (Codex Austriacus), prior to the French Code Civil being received in Austria and remaining operational until the Allgemeines Bürgerliches Gesetzbuch (ABGB) became law in 1811. In view of the author's close link with the University of Vienna, one can understand his going into the historical background of the ABGB more deeply than he does the other codifications. He also addresses, in some depth, the meaning and effect of the ABGB on Austrian legal development in general and its influence on other legal systems, including those of Poland, Hungary and Upper Italy (Oberitalien). He observes that it has been strongly influenced by German law and throughout by natural law and canon law principles, but it demonstrates minimal influence by the ALR and the French Code Civil. In natural law sense its principles could be applied consistently and everywhere. That is why it was applied over a wide area outside Austria.

Further to the discussion of natural law and codifications, chapter 8 deals with the European private law families around 1800. In this regard the focus is on the families constituting English common law, Scandinavian law and continental European law with particular reference to the role of universities, jurists, the courts and the legislature in applying and developing the law and in establishing the special links between these families of law.

Chapter 9 deals with schools of legal science within the bounds of codifications. At the outset the exegetic school of the ABGB is discussed as the first postcodification school of law in Europe. The focus is primarily on the methods employed by prominent representatives of the school in its exegesis of the Romano-Germanic roots of the ABGB. A number of dogmatic examples are presented to illustrate this method from a German-Austrian private law perspective and in its Austro-Italian jurisprudential context. This is followed by a succinct discussion of the methods of the exegetic school (École de l'exégèse) of the Code Civil, which relates to French law as opposed to the methods of the ABGB exegetic school, which is focussed on Austria. These schools continued their activities until well into the eighteenth century, the French enduring some fifty years longer than the Austrian.

The Historical School (die Historische Rechtsschule), in the sense of a nationalhistorical-systematic (nationalhistorisch-systematische) law school, is discussed in chapter 10. It takes its historical matter from the legal development of a particular nation with a view to creating a systematic unity from the norms and principles of the existing legal order. This differs from ideas on enlightenment and rationality or reasonableness as set forth in logically constructed natural law and, to a certain extent also, from thought on codification. 
Among the important exponents of the Historical School were Gustav Hugo (1764-1844) and Karl Friedrich Eichhorn (1781-1854), but it was particularly Friedrich Carl von Savigny (1779-1860) with his History of Roman Law in the Middle Ages (Geschichte des Römischen Rechts im Mittelalter, 1834-1851), System of Current Roman Law (System des heutigen Römischen Rechts, 1840-1849) and Calling of our Time for Legislation and Legal Science (Vom Beruf unserer Zeit für Gesetzgebung und Rechtswissenschaft, 1840), who demonstrated his hostility to codifications such as the ALR, ABGB and Code Civil. This gave rise to what became known as the "historical-systematic method" (die historisch-systematische Methode) in the sense that legal science was historical science in that it relied on legal principles extracted from historical sources for use in creating a unified system of current law. Inasmuch as the systematising of the law was based on logical grounds it was not, however, strictly historical. Although the divisions of the law were generally based on those occurring in the Pandects (Digesta) of Justinian, the term "Pandectism" (Pandektistik) came to be regarded as a form of "terminological jurisprudence" (Begriffsjurisprudenz). The author refers to this as "scientific positivism" (wissenschaftlicher Positivismus) and suggests that the dogmatism (Dogmatik) arising from the Pandects is in fact linked to natural law thought. This prompted a jurist like Bernhard Windscheid (1817-1892) to name his work on the Pandects a Text-Book on Pandect Law (Lehrbuch des Pandektenrechts).

A German branch of the Historical School related to German rather than Roman law and was termed "German philology" (Germanistik). Although its terminology was essentially that of the Pandektistik, it was not similarly hostile to codification, as appears from the work of Anton Friedrich Justus Thibaut (1772-1840) "on the necessity of a general civil code for Germany" (Über die Notwendigkeit eines allgemeinen bürgerlichen Rechts für Deutschland (1814)). This gave rise to a codification conflict (Kodifikationsstreit) which resulted in success for the anticodification group.

The topic was extended to a differentiation between regions without modern codifications and codification areas such as Austria. This gave rise to Pandectist innovations of the ABGB and East-European renditions thereof. From there it spread to other parts of Europe and overseas countries such as the Far East and a number of South American countries. A variety of important contributions emanated from the areas of Pandektistik and Germanistik, with canon law having no small influence and dogmatic changes also becoming prevalent.

A logical extension of this topic appears in chapter 11 where Pandectist codifications are discussed. This went hand in hand with historical and political events. In Germany it commenced with a general statute on bills of exchange (Allgemeine Deutsche Wechselordnung) in 1848 and a general commercial code (Allgemeine Deutsche Handelsgesetzbuch) in 1861. A number of smaller private law codifications preceded the German Bürgerliches Gesetzbuch (BGB), which is 
regarded as the most significant of the Pandectist codifications. It was approved and published in 1896 but only came into operation on 1 January 1900. In accordance with the Pandectist system it was divided into a general section, followed by sections on obligations, things, family and succession. It enjoyed a wide sphere of influence, including Switzerland, Austria, Greece, Japan, China, Brazil and Peru and, more recently, during the twentieth century, the former East-Block countries.

This chapter continues with a discussion of the Pandectist codifications of Switzerland with its canton system. The codification movement commenced with the promulgation of Cantonese codes of private law in Bern, Luzern, Genf, Tessin and Zurich, which were followed by the influential Code of Obligations (Obligationenrecht) of 1883 before culminating in the Swiss civil code (Schweizerisches Zivilgesetzbuch) of 1912. These two codes, which are read and applied together, were particularly influential in countries like Turkey, Liechtenstein and Italy, but also played a role in the development of law in Yugoslavia and other South-East European countries, while exerting some influence in Peru and China.

It is interesting to note that in Austria there was discussion as early as 1850 of a Pandectist civil code to take the place of the ABGB of 1811. Initially it was directed at the adaptation of aspects of private law such as marriage law for Catholics and the supplementing or amendment ("novation") (Novellierung) of parts of the ABGB. This gave rise to the three partial "novations" (Teilnovellen) relating to the law of persons and succession (1914), the drawing of boundaries (1915) and the law of things and obligations (1916). It also resulted in dogmatic innovations such as the abolition of the Roman legal rule that improvements fall to the land on which they are built (superficies solo cedit).

Chapter 12 contains a discussion of reactions, during the latter part of the nineteenth century, to Pandectism (Pandektistik) and German philology (Germanistik) as "terminological jurisprudence" (Begriffsjurisprudenz). The essence of the criticism was that it was not sufficient to collect law into a series of terms or concepts, to distinguish legal principles logically and to apply such principles mechanically. It was not merely a matter of terminology, but of interests, evaluation and the application of living law. This appears from works of jurists like Rudolf von Jhering (1818-1892), who was originally an exponent of Begriffsjurisprudenz but turned to the jurisprudence of interests (Interessen-jurisprudenz) with his "struggle for law" (Kampf ums Recht) of 1872 and "purpose in law" (Zweck im Recht) of 1877. Studies like this related to sociological considerations and the intention and object of the legislator in achieving a balance or equalisation of interests (Interessenausgleich).

Alongside this developed a jurisprudence of evaluation (Wertungsjurisprudenz) regarding an appreciation of the values emanating from various interests. In doing so use was made of a "natural-historical method" (naturhistorisches Methode) based on life experience, and hence referred to as a jurisprudence of "experiential science" (Erfahrungswissenschaft). This gave rise to the so-called "free" or "independent" 
law schools of jurists like Hermann Kantorowicz (1877-1940) who focussed on general clauses such as good faith (Treu und Glauben), good morals (gute Sitten) and equitable considerations (billiges Ermessen) in legal practice. Their attention was also directed to the correction or modification of statutes, particularly after the World Wars when the law relating to labour and social matters (Arbeits- und Sozialrecht) required special consideration next to issues of private law.

Chapter 13 deals with the private law of totalitarian states with their particular ideologies, characterised by a restriction of private autonomy and a selective distribution of property to individuals. A good example is the socialist legal family (sozialistischer Rechtskreis) which, since the dissolution of the East-Block and other fascistic or authoritarian states, has become limited to countries like China, North Korea, Vietnam and Cuba. In this regard the author deals with the theoretical and practical aspects of National-Socialism (Nazionalsozialismus) and private law and gives some dogmatic examples by way of illustration. He deals in similar vein with the (now former) Deutsche Demokratische Republik (DDR or East Germany) as a member of the socialist legal family.

The topics of "de-codification" and "re-codification" are dealt with in chapter 14. The majority of former East-European countries and members of the erstwhile Soviet Union moved away from the codification idea, and hence "de-codified", but a country like the Netherlands produced a new code of civil law (Nieuw Burgerlijk Wetboek) in the period between 1970 and 1992. This was then a "re-codification" on a grand scale, as opposed to a partial codification movement in a number of former East-Block countries. In this regard the author discusses spheres of law reform and gives a number of dogmatic examples by way of illustration.

The concluding chapter 15 contains a brief presentation of private law families in the period around 2000, bearing in mind that the BGB celebrated its $100^{\text {th }}$ year of existence in 2000 and the Code Civil and ABGB their 200 $0^{\text {th }}$ in 2004 and 2011 respectively. The author initially addresses the law of Continental Europe and follows this up with an overview of the Scandinavian and Socialist legal families before turning finally to the Common Law. He points out that the Scandinavian countries have retained their unique nature, characterised by the fact that they have no codifications comparable with those of Europe, while there are no longer any European countries in the Socialist legal family. The Common Law of England, he observes, is characterised by its system of binding precedents (stare decisis), while the United States of America has gained recognition for its Uniform Commercial Code of 1956 and its acceptance of the Common Law marriage based on the principle of agreement (consensus facit nuptias). In all these legal systems and families of law, however, the historical foundations of European law continue to play a significant role.

This overview of European legal history constitutes a valuable contribution to legal history in general and to comparative law in a wide-ranging historical context 
in particular. It is clearly of great use to law students in Austria, where the author is a professor of legal history at the University of Vienna, and to other countries in Europe, including Hungary, where the author is an honorary professor of legal history at the Budapest University. Indeed his work has been translated into Hungarian, hence making it easily accessible to his Hungarian students. It goes without saying that I strongly recommend it to any legal historian engaged in legal historical research or simply having an interest in the legal sphere covered by the work.

The Honourable Mr Justice DH van Zyl

Cape Town 